\title{
A revision of the abandoned snailfish genus Menziesichthys with description of a new species (Teleostei, Scorpaeniformes, Liparidae)
}

\author{
Artem M. Prokofiev ${ }^{1,2}$, Alexandru Iftime ${ }^{3}$ \\ 1 A. N. Severtsov Institute of Ecology and Evolution, Russian Academy of Sciences, Leninskii prospect \\ 33, Moscow 119071, Russia \\ 2 P. P. Shirshov Institute of Oceanology, Russian Academy of Sciences, Nakhimovsky prospect 36, \\ Moscow 117218, Russia \\ 3 “Grigore Antipa” National Museum of Natural History, Kiseleff boulevard 1, Bucharest 011341, \\ Romania
}

Corresponding author: Alexandru Iftime (aiftime@antipa.ro)

Received 6 November 2019 | Accepted 9 March 2020 | Published 30 June 2020

Citation: Prokofiev AM, Iftime A (2020) A revision of the abandoned snailfish genus Menziesichthys with description of a new species (Teleostei, Scorpaeniformes, Liparidae). Travaux du Muséum National d'Histoire Naturelle "Grigore Antipa” 63(1): 93-115. https://doi.org/10.3897/travaux.63.e48237

\begin{abstract}
The genus Menziesichthys is revised and re-diagnosed, its type-species, M. bacescui, is redescribed and a new species is described. Menziesichthys shares intermediate morphological characters between the genera Psednos and Rhodichthys. It is unique within all liparid genera in the combination of strongly humpbacked body, uninterrupted infraorbital canal with huge pore openings, relative position of second nasal pore and nostril, very large gill slits, and diminutive size of adult specimens. A new species, M. alaid, is described from the Sea of Okhotsk off the northern Kuriles. It differs from the type-species (distributed in the southeastern Pacific) in having a lower pectoral-fin ray count, more anteriorly situated anus, minute (vs. well-developed) protrusion at the posterior end of the maxilla and in other minor characters.
\end{abstract}

\section{Keywords}

Snailfishes, Menziesichthys, Psednos, Rhodichthys, new species, taxonomy, Pacific Ocean. 


\section{Introduction}

During the $11^{\text {th }}$ cruise of the R/V Anton Bruun in 1965 an unusual specimen of Liparidae was collected from the Peru-Chile Trench at depths of 1296-1317 m. This was described as a new genus and species, Menziesichthys bacescui, by Nalbant and Mayer (1971). No subsequent worker has made attempts to re-investigate this specimen. Stein et al. (1991) and Chernova et al. (2004) considered this taxon as a probable ophidioid but gave no justification for this conclusion. In sorting the specimens collected during the North Pacific cruises of R/V Vityaz and housed in the Institute of Oceanology, Russian Academy of Sciences, the first author discovered two unusual liparids collected in the Sea of Okhotsk off the Atlasov Island north of the Paramushir Island in the northern Kuriles at a depth of $820 \mathrm{~m}$. At first glance they appeared to be members of the mainly mesopelagic genus Psednos Barnard, 1927, which is worldwide in distribution but not yet recorded from the Russian Far Eastern waters. However, these specimens differ markedly from Psednos in the structure of the cephalic laterosensory canals and in the enormous size of the gill openings. The first author also noted the striking similarity between these specimens and a drawing of M. bacescui in the original description of Nalbant and Mayer (1971, Figs $6 \mathrm{a}, 6 \mathrm{~b})$. The second author reexamined the holotype of $M$. bacescui and confirmed its similarity with the Okhotsk specimens, although some differences clearly suggest their belonging to a different species. The present paper is devoted to the resurrection of the genus Menziesichthys, restoring its status as a snailfish, and description of a new species from the Sea of Okhotsk.

\section{Methods}

Counts, measurements and terminology follow Andriashev (2003). All measurements were made point to point. Radiographs were inconclusive due to condition of specimens; therefore, vertebral counts were derived by counting myomeres (it was also possible to count vertebrae of posterior half of vertebral column directly through translucent light). A weak solution of the black gouache paint was injected into cephalic sensory canals for determination of their configuration. The pectoral girdle was cleared and stained following a method described by Andriashev et al. (1977).

Abbreviations used in the text: SL, standard length; HL, head length; FRV, fishery research vessel; R/V, research vessel; sta., oceanographic station. Collection acronyms follow Fricke and Eschmeyer (2020).

Abbreviations used in the figures:

$\mathrm{AN}$ - anus

app - apices of ascending processes of the premaxillaries 
cor - coronal pore

CR - coracoid

$\mathrm{fp}$ - fleshy appendix at the posterior end of the maxilla

I - apex of isthmus

iol-5 - infraorbital pores 1 to 5

lgs - lower end of gill slit

$\mathrm{N}$ - nostril

$\mathrm{n} 1, \mathrm{n} 2$ - nasal pores 1 and 2

PC - pyloric caeca

pm1-7 - preoperculo-mandibular pores 1 to 7

psg - premaxillary symphyseal gap

R1-4 - pectoral radials 1 to 4

rar - retroarticular process of the lower jaw

SC - scapula

ss - symphyseal spines of dentary

sst - suborbital stay

ST - stomach

$\mathrm{T}$ - testis

t1 - first temporal pore

$\mathrm{tt}$ - suprabranchial pore

\section{Taxonomy}

\section{Menziesichthys Nalbant \& Mayer, 1971}

Figs $1-8$, 9A

Type-species: M. bacescui Nalbant \& Mayer, 1971 [by original designation and monotypy].

Diagnosis. A genus of diminutive snailfishes (maximum known size $57 \mathrm{~mm}$ SL) unique in the possession of an extremely large gill opening ending well in front of lower end of pectoral-fin base (Figs 2C, 2E, 7B), 76-80 \% HL in length; second nasal pore positioned medial to nostril (Figs 2A, 2D); lips with a minute to welldeveloped barbel-like fleshy projection at the posterior end of the maxilla (Figs $2 \mathrm{~B}, 3 \mathrm{~A}, 8 \mathrm{~B})$. The genus is further distinguished by the following combination of non-unique characters: one nostril; mouth strongly oblique, mandibular symphysis with a pair of small projections (Fig. 3B); body markedly hump-backed as vertebral column strongly flexed anteriorly (Figs 1, 5D, 7A); infraorbital sensory canal not interrupted, coronal pore present, sensory-pore openings very large (except coronal pore) (Figs $2 \mathrm{~A}-\mathrm{D}, 8 \mathrm{~A}, 9 \mathrm{~A}$ ); pectoral fin with $13-24$ rays, pectoral-fin notch shallow; four large bony pectoral radials occupying most of the area of the basal plate (status unknown for M. bacescui). 
Characters shared by both known species of Menziesichthys. In order to avoid repetition, we include them under a single heading and then elaborate as necessary under the individual species accounts.

Body tadpole-shaped (Figs 1, 7); occiput strongly humped; dorsal outline declining sharply from occiput caudally; caudal portion of body (behind anal-fin origin) slender and diminishing distally. Head large (Figs 1-3, 7, 8); snout as long as eye; interorbital space broad and convex; mouth gape large, ending below hind margin of orbit, strongly oblique; symphysis of lower jaw with a pair of small wellseparated spines (Fig. 3B). Premaxillaries apparently very protractile, with ascending processes rather long, equal to vertical diameter of eye in length, their distal tips forming a small protuberance when viewed laterally (Figs 2B, 8A). Jaw teeth small, pointed (Fig. 3C), those of premaxilla slightly larger; premaxillary teeth arranged in three irregular rows near symphysis, decreasing to 1-2 interspersed rows toward rictus, more spaced than those on dentary; dentary teeth arranged in 2-3 irregular (interspersed) rows at symphysis, rapidly decreasing to a single row backward; both upper- and lower-jaw teeth reaching toward rictus. Vomer and palatines toothless. Tongue large and massive, free. Nostril single, close to anterior border of eye. Opercular bone very narrow, curved posteroventrally, its distal tip reaching upper end of pectoral-fin base. Branchiostegal rays six in number. Gill opening large, its upper end level with upper margin of orbit; gill slit descending to ventral surface of head and ending at vertical of interspace between third and fourth infraorbital pores, well in front of lower end of pectoral-fin base (Figs 2C, 2E, 7B). Pseudobranch absent.

All fin rays simple, articulated. Upper end of pectoral-fin base level with fourth infraorbital pore. Pectoral-fin with broadly and shallowly notched margin, its rays readily visible externally (Figs $2 \mathrm{C}, 7 \mathrm{C}$ ); shortest ray in notch about 0.5 of longest pectoral-fin ray. Lower end of pectoral-fin base situated on the same vertical as opercular-hyomandibular joint, those of right and left pectoral fins widely separated (Figs 2C, 7B). Apex of isthmus produced forward. Ventral disk absent. Beginning of vertebral column sharply curved dorsally (Fig. 5D). Hypural plate narrow and elongate, lacking a slit (Fig. 5F).

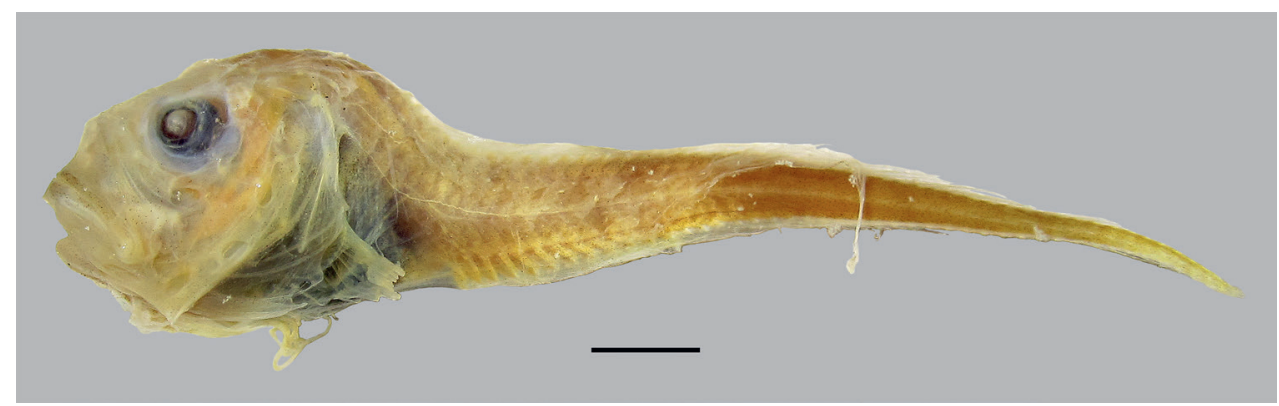

Figure 1. Menziesichthys alaid, new species, holotype, habitus, lateral view. Scale bar: $5 \mathrm{~mm}$. 


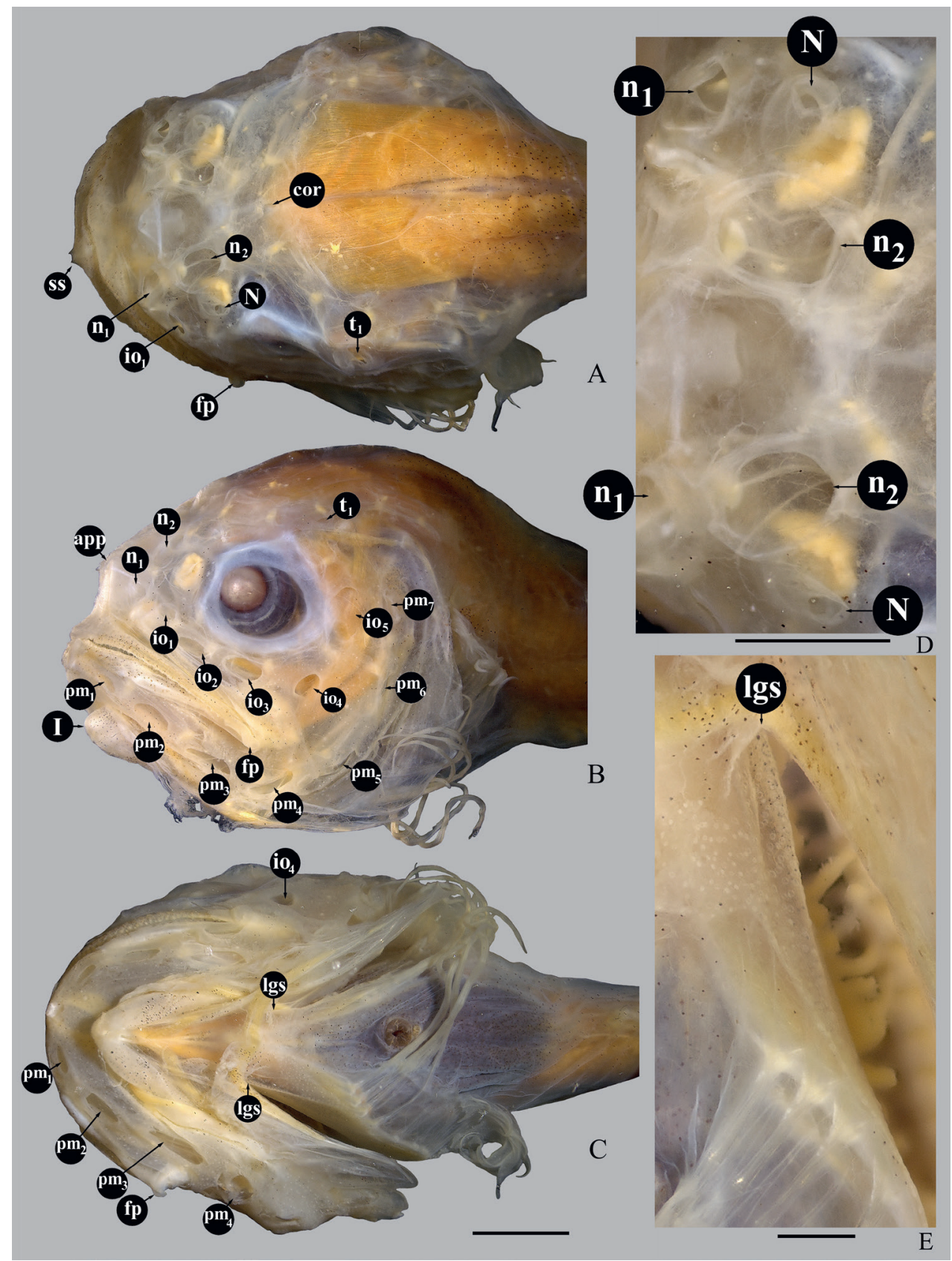

Figure 2. Menziesichthys alaid, new species, holotype: A-C - head (A - dorsal view, B - fronto-lateral view, $\mathrm{C}$ - ventral view), D - relative position of nasal pores and nostril, $\mathrm{E}$ - ventral ending of gill slit. Scale bars: A-C $-2.5 \mathrm{~mm}$ (common bar), D, E - $1 \mathrm{~mm}$. 
Species. Menziesichthys currently includes two species, M. alaid (new species) and M. bacescui, from northwestern and southeastern Pacific Ocean, respectively (Fig. 6).

Comparisons. Menziesichthys is morphologically intermediate between the genera Psednos Barnard, 1927 and Rhodichthys Collett, 1879. It is similar to Psednos and differs from Rhodichthys in possessing an anteriorly flexed vertebral column making body markedly hump-backed, in its diminutive size, oblique mouth, pectoral fins only shallowly notched and not forming a "pseudoventral fin". It is similar to Rhodichthys and differs from Psednos in its possession of an uninterrupted infraorbital canal, large sensory pore openings, and large gill slit (even larger in Menziesichthys than in Rhodichthys: 76-80 \% vs. 54-72 \% HL). Menziesichthys differs from both these genera in the more generalized structure of its pelvic girdle that has four large equidistant and closely spaced bony radials (vs. usually three radials, rarely four in Rhodichthys and in Psednos longiventris Stein, 2012 (aberrant condition?), and three uppermost radials widely separated from the lowermost one). In the structure of the pectoral girdle Menziesichthys resembles certain species of Paraliparis Collett, 1879 (e.g., P. eltanini Stein \& Tompkins, 1989; P. gracilis Norman, 1930; P. hubbsi Andriashev, 1986; P. valentinae Andriashev \& Neelov, 1984, etc.: Andriashev 2003). However, no Paraliparis species possesses so large a gill slit that extends far below the lowermost pectoral-fin rays, and a hump-backed body with anteriorly flexed vertebral column. Two features of Menziesichthys are not found in any liparid genera: second nasal pore positioned mesial to nostril (vs. behind it in Psednos or before the level of nostril(s) in the other liparid genera) and presence of a barbel-like fleshy projection at the posterior end of the maxilla (although very small in M. alaid).

\section{Menziesichthys alaid new species}

Figs 1-6, 9A

Holotype. IOM nr. 3609, $46 \mathrm{~mm}$ SL (Fig. 1), Okhotsk Sea northward from Paramushir Island, $51^{\circ} 10^{\prime} \mathrm{N}, 154^{\circ} 40^{\prime} \mathrm{E}, 820 \mathrm{~m}$, sandy-mud bottom, Sigsbee trawl, R/V Vityaz sta. 126, 21 September 1949. In fairly good condition.

Paratype. IOM nr. 3610, $57 \mathrm{~mm}$ SL, collected with the holotype. Right pectoral girdle removed, cleared \& stained with alizarin red S.

Diagnosis. A species of Menziesichthys with minute fleshy protrusion at posterior end of maxilla (Figs 2A, 2B, 3A), 13-14 pectoral-fin rays, and anus equidistant from anal-fin origin and from chin, or slightly closer to the latter (Fig. 2C).

Description. Eye with somewhat eccentric lens (semi-telescopic) (Figs 1, 2B). Mouth gape forming an angle of about $40^{\circ}$ to longitudinal axis of body. Lower jaw slightly projecting (Figs $2 \mathrm{~B}, 3 \mathrm{~B}$ ). Retroarticular process of lower jaw forming strong, sharp triangular spine (Fig. 3A). Lips forming small fleshy protrusion at posterior end of maxilla. Premaxillary symphyseal gap moderately broad, about 3 times wider than width of premaxillary tooth band at symphysis; dentary symphyseal gap nar- 


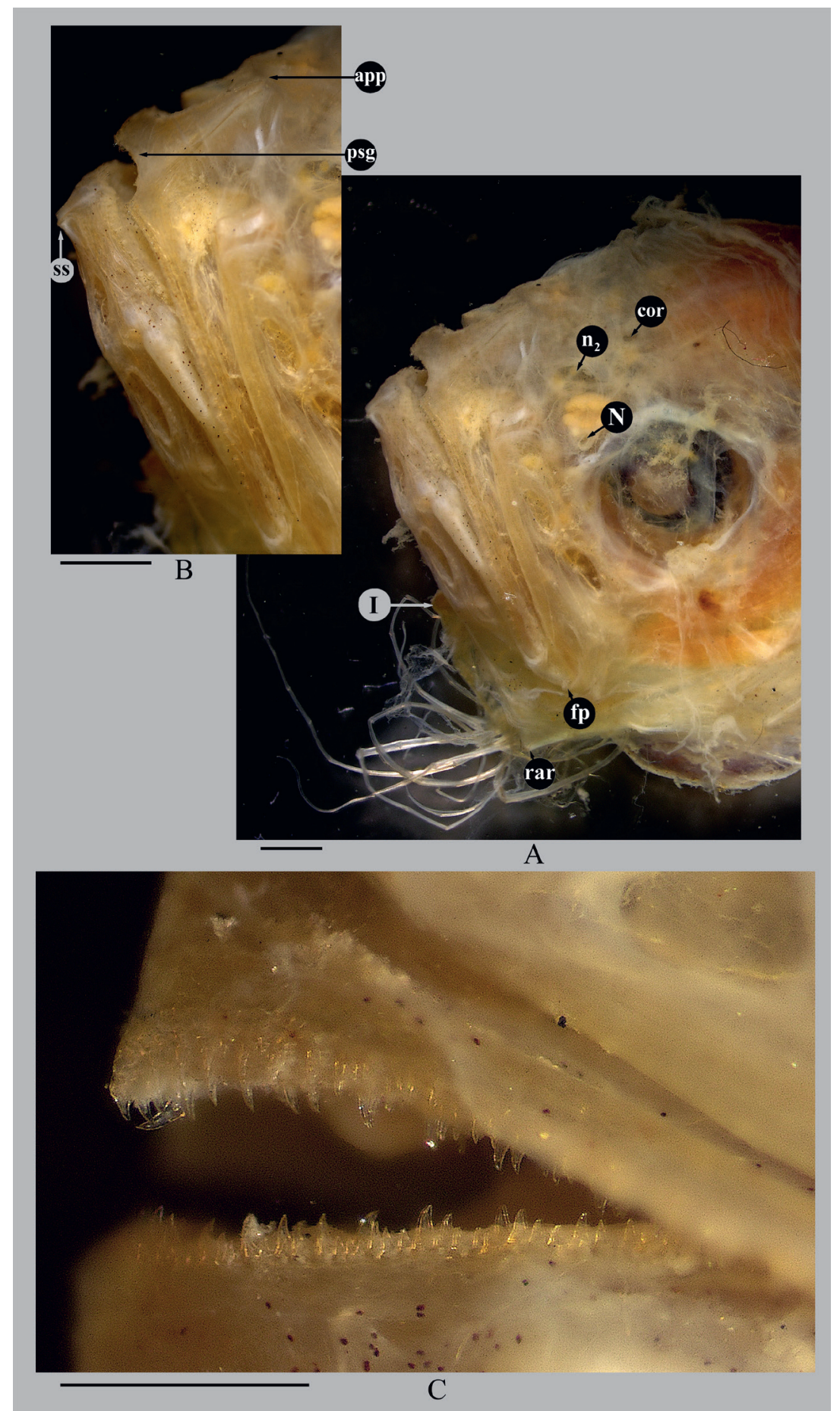

Figure 3. Menziesichthys alaid, new species, paratype: A - head, fronto-lateral view, B - symphyseal portions of jaws, $\mathrm{C}$ - jaw dentition. Scale bars $-1 \mathrm{~mm}$. 
row, as wide as width of dentary tooth band at symphysis. Jaw teeth unequal in size on both jaws; inner teeth larger than outer ones (Fig. 3C); teeth of posterior portion of premaxilla visible from below when mouth closed. Diameter of olfactory organ slightly smaller than that of pupil. Burke's (1930) pore formula: 2-6-7-1; coronal pore present. Sensory-pore openings large ( $\times 0.5-1.0$ of pupil diameter), except coronal pore (about $1 / 3$ of pupil diameter). Second nasal pore larger than olfactory organ and situated on the same level medially from the latter (Figs 2A, 2D, 3A). Infraorbital canal not interrupted behind eye (Figs 2B, 9A); its first pore situated above the level of second and third pores, equidistant from second infraorbital and first nasal pores; fourth pore positioned at posteroventral border of orbit, fifth pore situated behind orbit. First pair of mandibular pores widely separated (Fig. 2C); fourth pore situated on mandibular joint; sixth preoperculo-mandibular pore situated below the level of lower margin of orbit; uppermost (seventh) preoperculo-mandibular pore level with upper half of fifth infraorbital pore (Fig. 2B). Suprabranchial pore single, far above top of gill opening. First gill arch with 50 gill filaments, 19 rakers in outer row and 18 in inner row; second gill arch with 18 outer and 16 inner rakers; third gill arch with 16 outer and 15 inner rakers; fourth gill arch with 15 outer rakers, inner rakers absent, no slit behind it. Gill rakers alternating (except lowermost 3-4 pairs opposed), compressed anteroposteriorly and tapered toward tip (Figs 4A, 4B), with upper surface somewhat truncated, bearing denticles arranged in a $\mathrm{V}$-shaped patch along free edge (with few additional inner denticles at tips of some rakers) (Figs 4C, 4D).

Pectoral fin with 13 (14) rays, length of second ray nearly equal to pectoralfin base length (tips of rays strongly twisted making exact measurements impossible); ninth ray shortest, about 1.5 times shorter than second ray; four lowermost rays elongated, slightly thickened, separated from interradial membrane on about $3 / 4$ of their length, thread-like, about 1.5 times longer than second ray, reaching anal-fin origin. Pectoral girdle (Fig. 5A) bearing four large angularly-roundish bony radials almost equidistant from each other, occupying most area of cartilaginous basal plate; uppermost radial somewhat smaller than remaining ones; interspaces between first and second radials and between fourth radial and coracoid wider than these between scapula and first radial and between second to fourth radials (Figs 5A, 5B). Scapula and coracoid well-developed, coracoid larger, with better developed process; plate of coracoid pierced by a small foramen. Anus thoracal, about $1 \times$ its diameter behind a line connecting lower ends of bases of left and right pectoral fins; distance from chin to anus equal to or slightly shorter than distance from anus to anal-fin origin. Pyloric caeca 8, short and thick, two of them about 1.5 times longer than the other six. Pyloric caeca and intestine filled with benthic detritus. Paratype is a mature male with ripe gonads (Fig. 5C).

Caudal fin missing in both holotype and paratype. In holotype some of last caudal vertebrae had been lost (apparently in life), the ending covered with skin and forming a pseudocaudal. With the skin removed, the terminal vertebral centrum was a malformed distally pointed structure (Fig. $5 \mathrm{E}$ ). In the paratype, the skin was 


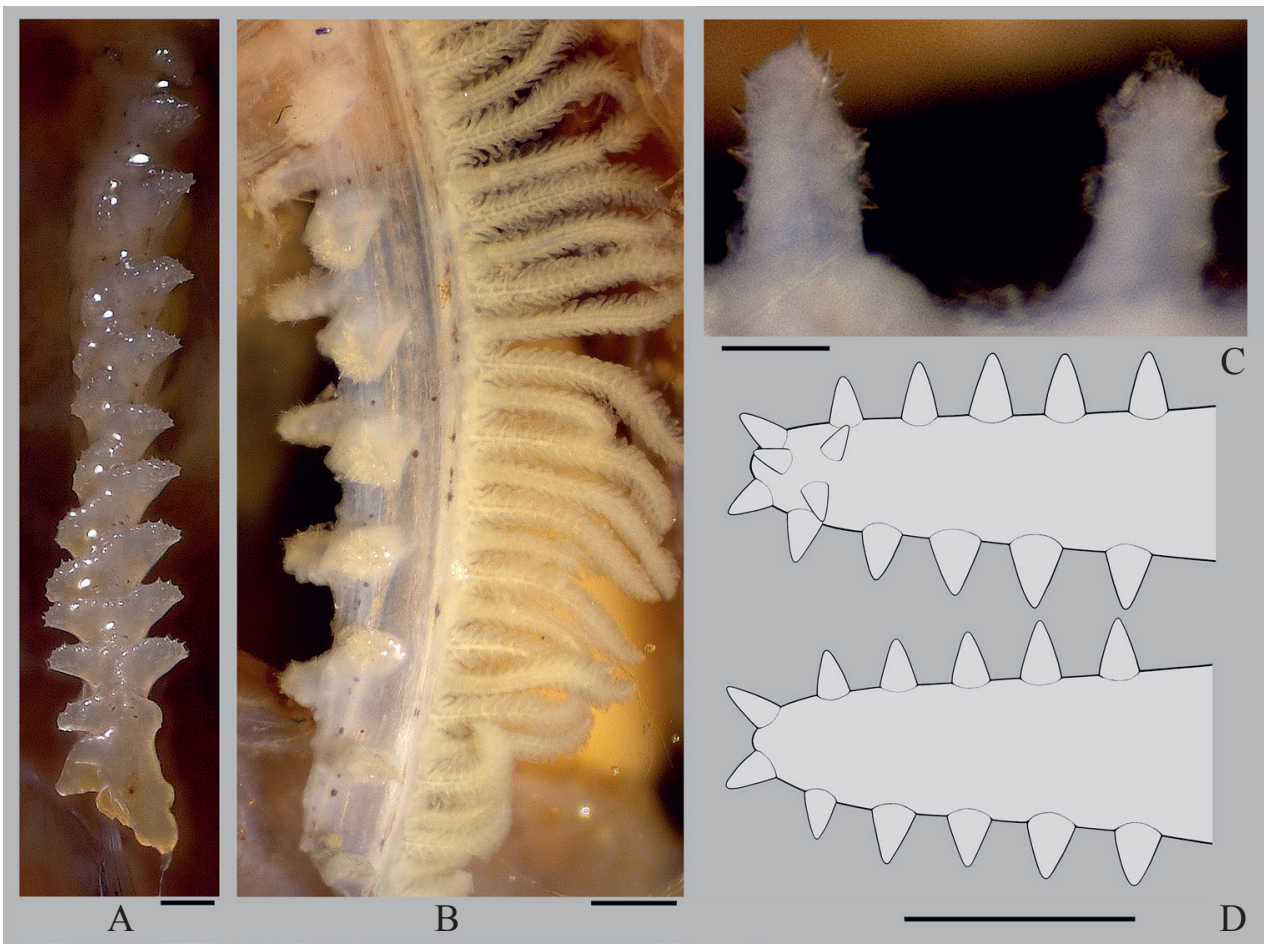

Figure 4. Menziesichthys alaid, new species, paratype: A, B - first gill arch (A - frontal view, B - lateral view), $\mathrm{C}-3^{\text {rd }}$ and $4^{\text {th }}$ rakers of first arch, dorsal view, D - variations in arrangement of denticles, dorsal view. Scale bars: A, B $-0.5 \mathrm{~mm}, \mathrm{C}, \mathrm{D}-0.25 \mathrm{~mm}$.

lost on several terminal vertebrae, but all vertebrae survived, the terminal centrum bearing a normally developed hypural plate hardly exceeding vertebral centra in depth (Fig. 5F). Vertebrae 58+ in holotype (61 in paratype); dorsal- and anal-fin rays $51+$ (ca. 60) and $46+$ (ca. 50), respectively. Anterior vertebral column sharply curved dorsally (Fig. 5D).

Skin thin, transparent, lacking pigmentation in preserved specimens. Small dotlike subdermal melanophores scattered over head and body, more densely concentrated on lips, isthmus, opercular membrane, predorsal region in front of dorsal-fin origin, pectoral-fin base, and especially in distal half of caudal portion of body and on belly. Oral and branchial cavities densely peppered with such melanophores; peritoneum dark (apparently black in life), translucent through body wall. Stomach as dark as peritoneum, pyloric caeca and intestine unpigmented. Overall melanophore pigmentation much less expressed in paratype, probably due to more abraded skin cover.

Measurements are summarized in Table 1. 
Etymology. The species is named after Alaid Volcano, located close to its type locality, the highest volcano in the Kuril Islands and a subject of much aesthetic praise described in the Japanese arts. It is treated as noun in apposition.

Comparisons. Other than for the characters given in the diagnoses of these species, $M$. alaid differs from $M$. bacescui in the orobranchial cavity densely peppered with melanophores (vs. oral cavity unpigmented and branchial cavity with diffuse

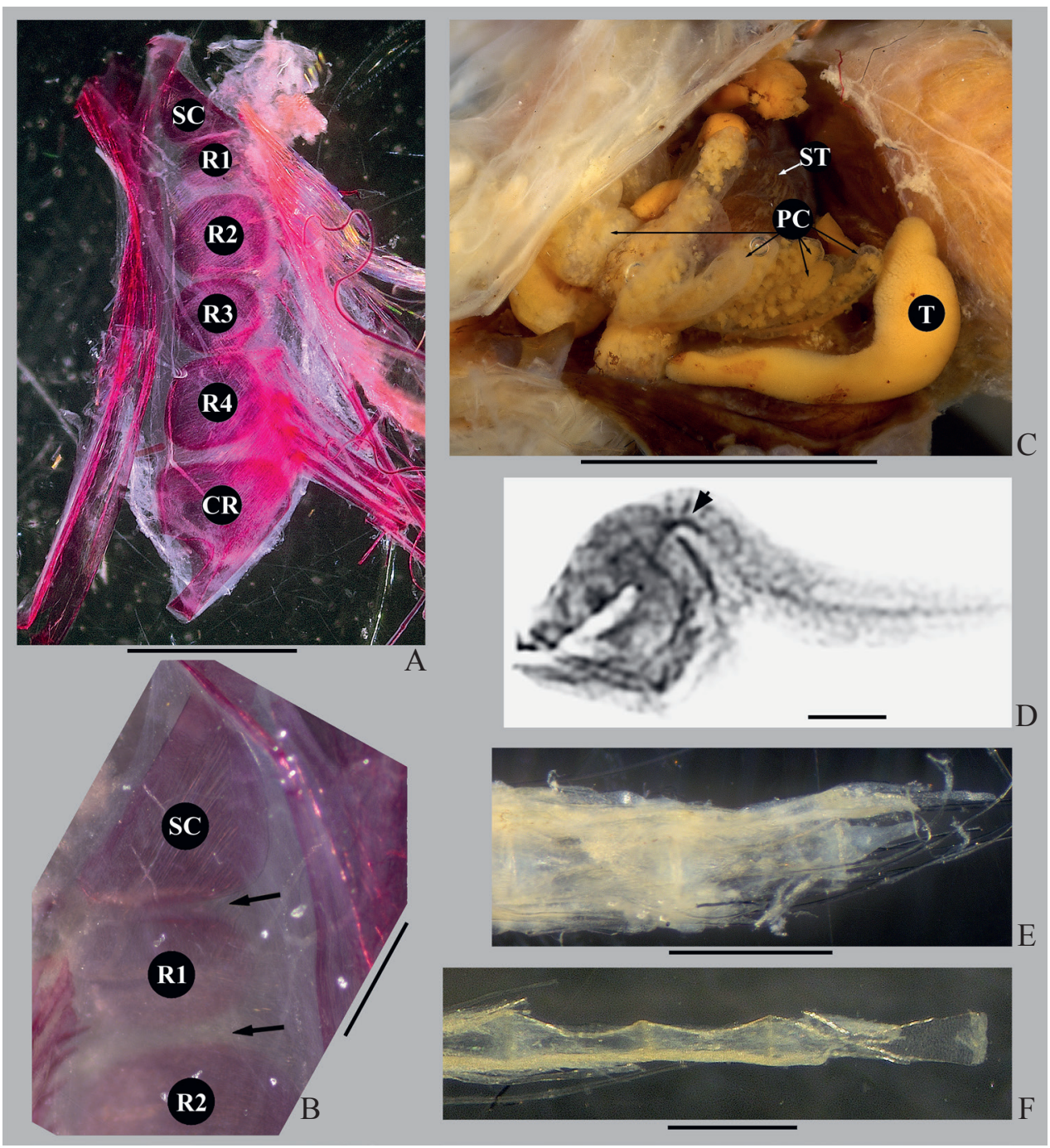

Figure 5. Menziesichthys alaid, new species, paratype (A-D, F) and holotype (E): A - pectoral girdle (cleared and stained), inner view, B - scapula and first pectoral radial, inner view (interspaces between scapula and first and second radials arrowed), $\mathrm{C}$ - gastrointestinal duct and gonad, D - radiograph showing anterior flexion of vertebral column (arrowed), E, F - last caudal vertebrae. Scale bars: A, C $-3 \mathrm{~mm}, \mathrm{~B}, \mathrm{E}, \mathrm{F}-1 \mathrm{~mm}, \mathrm{D}-5 \mathrm{~mm}$. 
solid dark pigmentation in $M$. bacescui), more numerous gill rakers (19 outer and 18 inner rakers on first arch vs. 12 and 10, respectively), both premaxillary and dentary symphyseal gaps broader and premaxillary teeth unequal (vs. equal) in size, and having a much larger olfactory organ (diameter $9.5-10.0 \%$ vs. $5.0 \% \mathrm{HL}$ ). However, more specimens in better condition are necessary to verify these differences.

\section{Menziesichthys bacescui Nalbant \& Mayer, 1971}

Figs 6-8

Holotype. NHMB nr. 169, $43.2 \mathrm{~mm}$ SL, Peru-Chile Trench, $08^{\circ} 21^{\prime} \mathrm{S}, 81^{\circ} 25^{\prime} \mathrm{W}$, 1269-1317 m, Menzies trawl, R/V Anton Bruun sta. 94, 14 October 1965. Currently in poor condition (stiffened by the ethanol conservant, skin and some soft tissue missing) (Figs 7A, 7B, 8A).

Diagnosis. A species of Menziesichthys with a well-developed barbel-like fleshy protrusion at posterior end of maxilla (Fig. 8B), 24 pectoral-fin rays, and anus situated about twice closer to anal-fin origin than to chin (Fig. 7B).

Description. Jaws equal in length. Mouth gape forming an angle of about $50^{\circ}$ to longitudinal axis of body. Retroarticular process of lower jaw forming less prominent spine than in previous species. Lips forming barbel-like fleshy protrusion at posterior end of maxilla (about 5.5 times in mouth gape length); no other barbels present, contrary to statement by Nalbant and Mayer (1971), who reported two pairs of barbels on lower jaw (their "anterior pair" actually represents the remnants of cartilaginous support of the lower lip) (Fig. 8A). Premaxillary symphyseal gap relatively narrow, about the same width as premaxillary tooth band at symphysis; dentary symphyseal gap absent or extremely narrow. Teeth equal in size on upper jaw, unequal on lower jaw. Contrary to statement by Nalbant and Mayer (1971) vomerine teeth absent (apparently gustatory papillae were misidentified for vomerine teeth in the original description). Diameter of olfactory organ notably smaller than that of pupil. Six mandibular pores, first pair widely separated. Apparently five infraorbital pores (area of fourth pore badly damaged), fifth pore largest (Fig. 8A). Two additional openings visible above and behind orbit, but it cannot be discerned whether they are part of the temporal or infraorbital sensory system or artifacts of preservation. Coronal pore present. Nasal pores together with nostril opening. Sensory-pore openings large $(\times 0.5-1.0$ of pupil diameter $)$, except coronal pore which is very small. No postopercular spines [artifact in Nalbant and Mayer (1971: fig. 6b)]. First gill arch with at least 32 gill filaments (some may have been lost when arch was removed), 12 rakers in outer row and 10 in inner row, alternating, except lowermost 2-3 pairs opposed. Rakers small, pyramid-shaped, tapered toward the tip, with truncate upper surface; denticles arranged in a V-shaped patch along free edge, relatively long, slender and sharp (Fig. 8C). Examination of remaining gill arches is currently impossible without damaging holotype.

Pectoral fin with 24 rays, $17^{\text {th }}$ ray shortest, about 1.5 times shorter than second ray; four lowermost rays elongated, slightly thickened, separated from interradial 


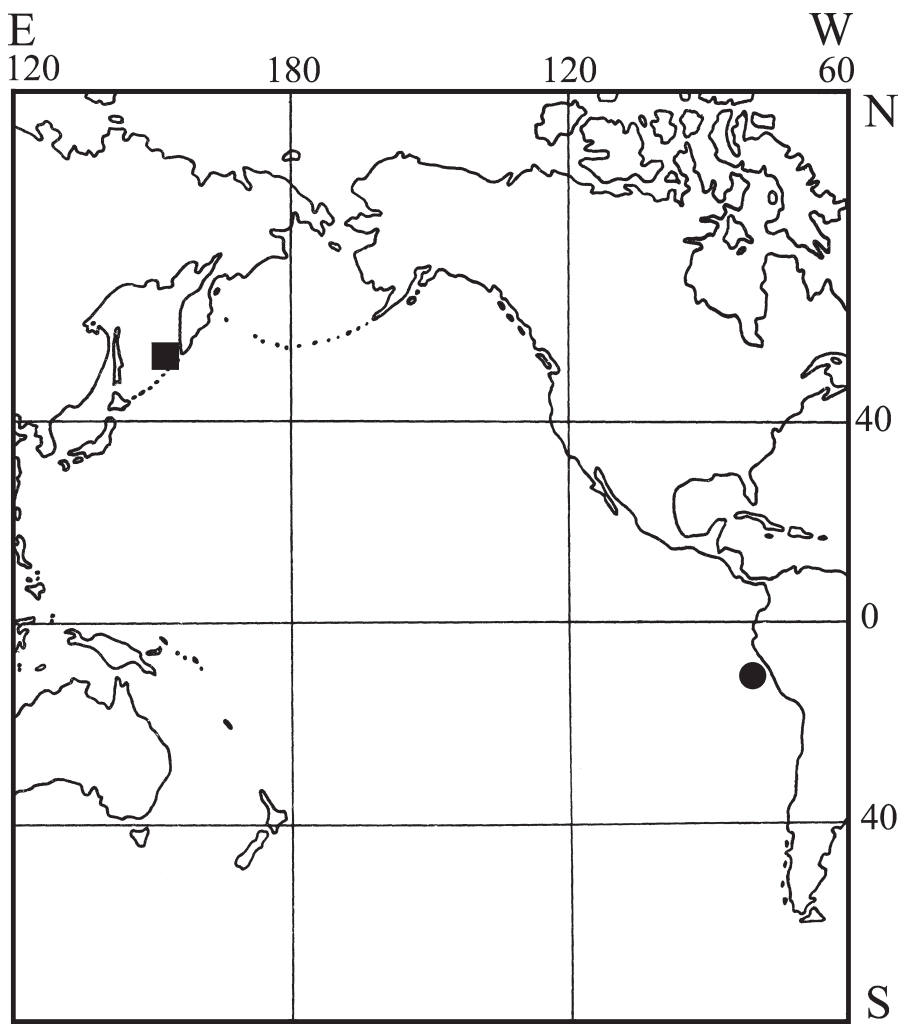

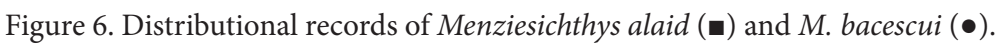

membrane at about $3 / 4$ of their length, thread-like. Anus abdominal, distance from chin to anus about twice the distance from anus to anal-fin origin. Caudal rays missing in holotype, however, all vertebrae remain; last vertebra with a well-developed hypural plate. Dorsal- and anal-fin rays ca. 60 each.

Skin thin, transparent, lacking pigmentation (melanophores may have been degraded by time and preservation). Interior of mouth lacking pigmentation, but branchial cavity pigmented (diffuse brown, with melanophores indiscernible). Peritoneum darkly and heavily pigmented (visible through translucent abdominal wall).

Measurements are summarized in Table 1.

\section{Discussion}

The family Liparidae currently comprises about 30 genera, but the validity of some of them is debated by various authors (Kido 1988; Andriashev 2003; Chernova et al. 2004; Stein 2012a, 2012b; Fricke et al. 2020). Certain genera are mono- or oligotypic and were based on a few features or even a single peculiar character. As a 
Table 1. Measurements of Menziesichthys spp. (some measurements for M. bacescui are difficult to do without risk of damage, or cannot be taken accurately anymore because of degradation).

\begin{tabular}{|c|c|c|c|}
\hline Character & M. alaid & & M. bacescui \\
\hline & Holotype & Paratype & Holotype \\
\hline SL, mm & 46 & 57 & 43 \\
\hline \multicolumn{4}{|c|}{ In $\%$ of $S L$} \\
\hline $\mathrm{HL}$ & 21.7 & 18.4 & 23.2 \\
\hline Greatest width of head & 15.2 & 12.3 & 12.7 \\
\hline Snout length & 5.4 & 4.9 & 4.6 \\
\hline Eye diameter & 5.4 & 4.9 & 4.6 \\
\hline Pupil diameter & 2.8 & 2.1 & - \\
\hline Diameter of olfactory organ & 2.2 & 1.8 & 1.2 \\
\hline Interorbital width & 12.0 & 8.8 & 5.8 \\
\hline Upper jaw length & 13.0 & 11.4 & 11.1 \\
\hline Lower jaw length & 13.0 & 12.3 & 13.8 \\
\hline Length of gill slit & 17.4 & 14.0 & 18.1 \\
\hline Length of pectoral-fin base & 8.7 & 8.8 & - \\
\hline Greatest depth of body & 19.6 & 17.5 & 19.5 \\
\hline Body depth at anal-fin origin & 10.9 & 8.8 & 9.3 \\
\hline Distance from snout to dorsal-fin origin & 23.9 & 19.3 & 24.3 \\
\hline Distance from snout to anal-fin origin & 30.4 & 22.8 & 30.1 \\
\hline Distance from chin to center of anus & 14.1 & 11.4 & 19.2 \\
\hline Distance from center of anus to anal-fin origin & 16.3 & 11.4 & 10.9 \\
\hline \multicolumn{4}{|c|}{ In $\%$ of HL } \\
\hline Greatest width of head & 70.0 & 66.7 & 54.9 \\
\hline Snout length & 25.0 & 26.7 & 20.0 \\
\hline Eye diameter & 25.0 & 26.7 & 20.0 \\
\hline Pupil diameter & 13.0 & 11.4 & - \\
\hline Diameter of olfactory organ & 10.0 & 9.5 & 5.0 \\
\hline Interorbital width & 55.0 & 47.6 & 25.0 \\
\hline Upper jaw length & 60.0 & 61.9 & 48.0 \\
\hline Lower jaw length & 60.0 & 66.7 & 53.3 \\
\hline Length of gill slit & 80.0 & 76.2 & 77.8 \\
\hline Length of pectoral-fin base & 40.0 & 47.6 & - \\
\hline Greatest depth of body & 90.0 & 95.2 & 82.5 \\
\hline Body depth at anal-fin origin & 50.0 & 47.6 & 40.0 \\
\hline Distance from snout to dorsal-fin origin & 110.0 & 104.8 & 90.2 \\
\hline Distance from snout to anal-fin origin & 140.0 & 123.8 & 129.7 \\
\hline Distance from chin to center of anus & 65.0 & 61.9 & 82.8 \\
\hline Distance from center of anus to anal-fin origin & 75.0 & 61.9 & 46.9 \\
\hline
\end{tabular}


result, their validity may, depending upon the adopted taxonomical perspective, require revision of some of the classic large genera with a more or less generalized combination of characters, like Liparis Scopoli, 1777; Careproctus Krøyer, 1862 or Paraliparis Collett, 1879. Routine tissue sampling of material will also greatly assist in confirming the validity of these genera. The only paper published to date focused on the phylogenetic analysis of the family based on a detailed anatomical study (Kido 1988) relied upon a limited number of species and specimens, mainly from Japanese waters. A more recent publication covering a molecular phylogeny of the Liparidae (Knudsen et al. 2007) was also based on a very restricted number of species (24), all from the northern hemisphere. The extremely diverse liparid fauna

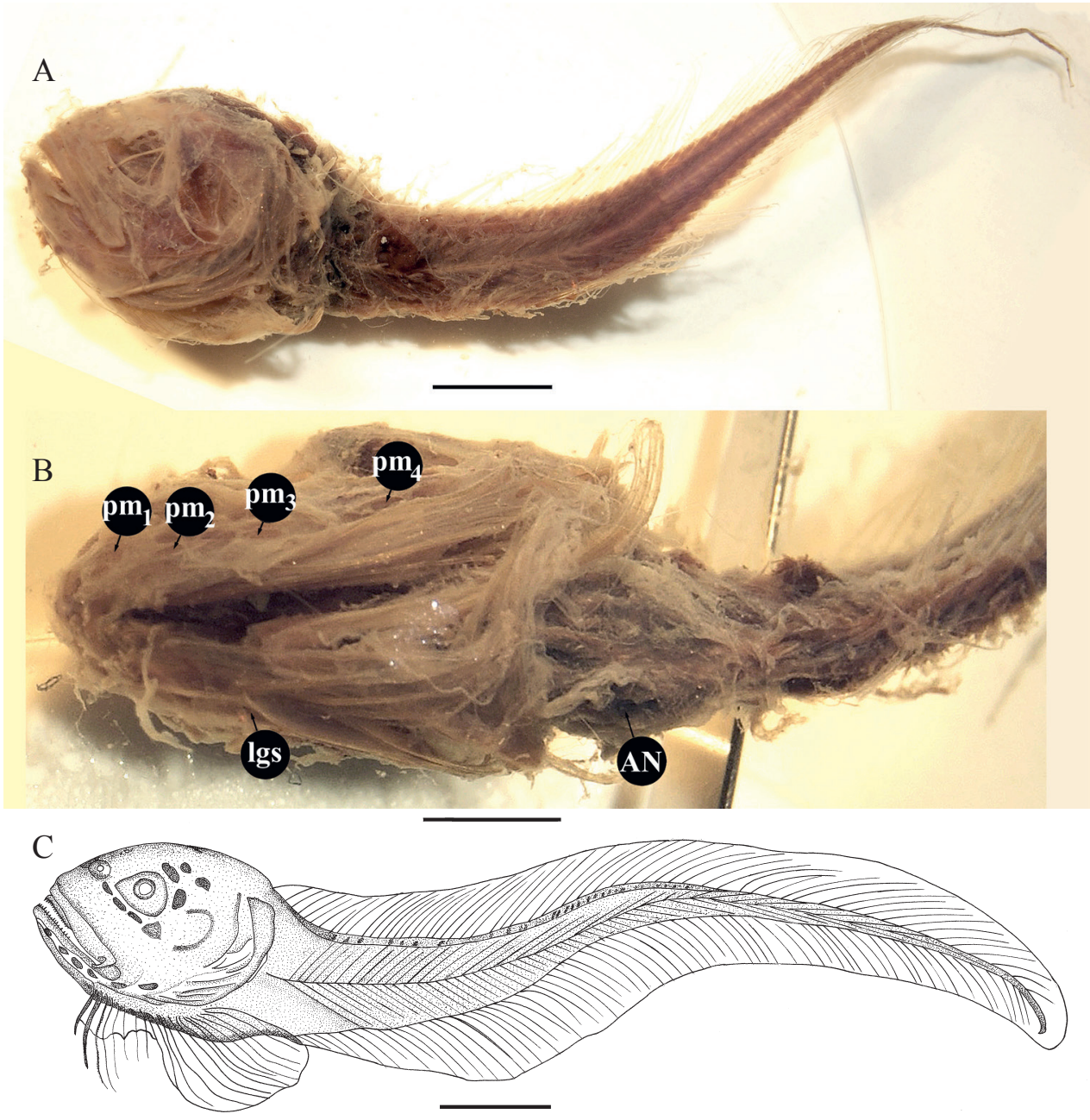

Figure 7. Menziesichthys bacescui, holotype: A - lateral view, B - ventral view of head and abdomen, $\mathrm{C}$ - restoration of holotype in lateral view. Scale bars: A, C $-5 \mathrm{~mm}, \mathrm{~B}-2.5 \mathrm{~mm}$. 


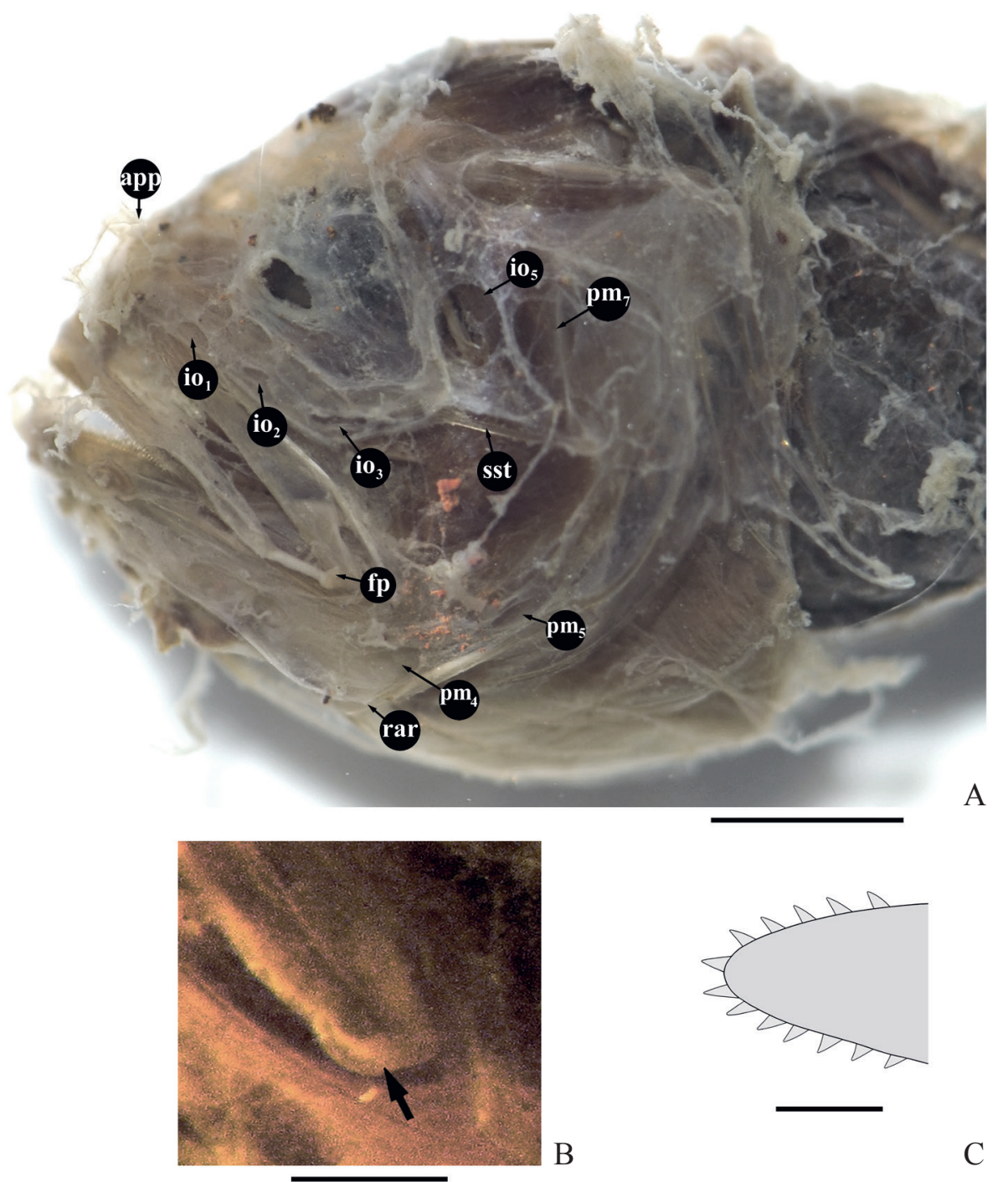

Figure 8. Menziesichthys bacescui, holotype: A - head, lateral view (right side, reversed), B - barbellike fleshy protrusion at posterior end of maxilla (arrowed), C - gill-raker of first arch, dorsal view. Scale bars: A $-2.5 \mathrm{~mm}, \mathrm{~B}-0.5 \mathrm{~mm}, \mathrm{C}-0.25 \mathrm{~mm}$.

from the southern hemisphere, comprising about 150 species (Andriashev 1986, 2003; Andriashev and Stein 1998; Stein et al. 2001; Stein 2012a, 2012b; Fricke et al. 2020) remains almost unstudied in internal anatomy although some molecular investigations have been recently published (Duhamel et al. 2010; Orr et al. 2019). As a result, the current paradigm of the genus-level systematics of the Liparidae may change drastically after a comprehensive morphological and molecular study of this family. 
Menziesichthys belongs to a group of genera characterized by the presence of six branchiostegal rays, a single pair of nostrils and by the absence of the ventral disc. It includes the nominal genera Paraliparis Collett, 1879; Rhodichthys Collett, 1879; Psednos Barnard, 1925; Genioliparis Andriashev \& Neelov, 1976; Odontoliparis Stein, 1978; Praematoliparis Andriashev, 2003; Aetheliparis Stein, 2012; Rhinoliparis Gilbert, 1896; Lipariscus Gilbert, 1915 and Edentoliparis Andriashev, 1990. Although accepted by some authors (Balushkin 1996; Andriashev 2003; Chernova et al. 2004) the last three genera are usually synonymized with Paraliparis (Kido 1988; Nakabo 2002; Duhamel et al. 2010; Stein 2012a; Orr et al. 2019). The monotypic Praematoliparis from the Strait of Magellan, Genioliparis (including Odontoliparis) with three north-eastern Pacific and Antarctic species and Aetheliparis with two species from the North Atlantic and South Pacific represent unusual genera sharing certain unique features (low dorsal and anal fin-ray count, unsegmented fin rays in Praematoliparis; predatory adaptations in Genioliparis; upturned mouth with a significantly concave lower jaw, enlarged gill cavity and remote position of pectoral fins in Aetheliparis); they are not discussed beyond this observation. Aetheliparis may be sunk within Psednos, as all its characters except those connecting with the peculiar enlargement of the gill cavity fully agree with Psednos. However, the unusual appearance of Aetheliparis (Chernova, Stein 2004; Stein 2012b) makes impossible its confusion with Menziesichthys. The remaining three genera (Paraliparis, Psednos, and Rhodichthys) appear to be most similar to Menziesichthys in morphological characters.

Superficially, Menziesichthys appears to be very similar to Psednos particularly in its humpbacked body formed by anterior flexion of the vertebral column, oblique mouth, small adult size, and similar meristics. For a long time Psednos was known by few specimens and believed by Stein (1978) to be an aberrant Paraliparis; however, it was resurrected as a valid genus by Andriashev (1992) and currently comprises several dozen described and undescribed species of worldwide distributions and mesopelagic habitats (e.g., Chernova 2001; Chernova and Stein 2002; Andriashev 2003; Stein 2012b; Fricke et al. 2020). Psednos has been characterized by a combination of three features, all unique within Liparidae: a humpbacked body formed by the anterior flexion of the vertebral column, the second nasal pore positioned behind the nostril, and the infraorbital canal widely interrupted below and behind the eye (Andriashev 1992, 2003; Chernova and Stein 2002; Stein 2012b). However, at least one species of Psednos lacks the anterior flexion of vertebral column and does not manifest a humpbacked body (P. microstomus Stein, 2012). Furthermore, the degree of development of the humpback is variable in other Psednos (Stein 2012b) making this character more quantitative than qualitative. On the other hand, as far as known, the interrupted infraorbital canal (Fig. 9B) represents a very stable feature of all known species of Psednos. Menziesichthys shares the humpbacked body (in a full form) but possesses an uninterrupted infraorbital canal, typical for all other Liparidae (Figs 9A, 9C), and has cephalic sensory pore openings much larger than in any Psednos. Psednos delawarei Chernova \& Stein, 2012 possesses 


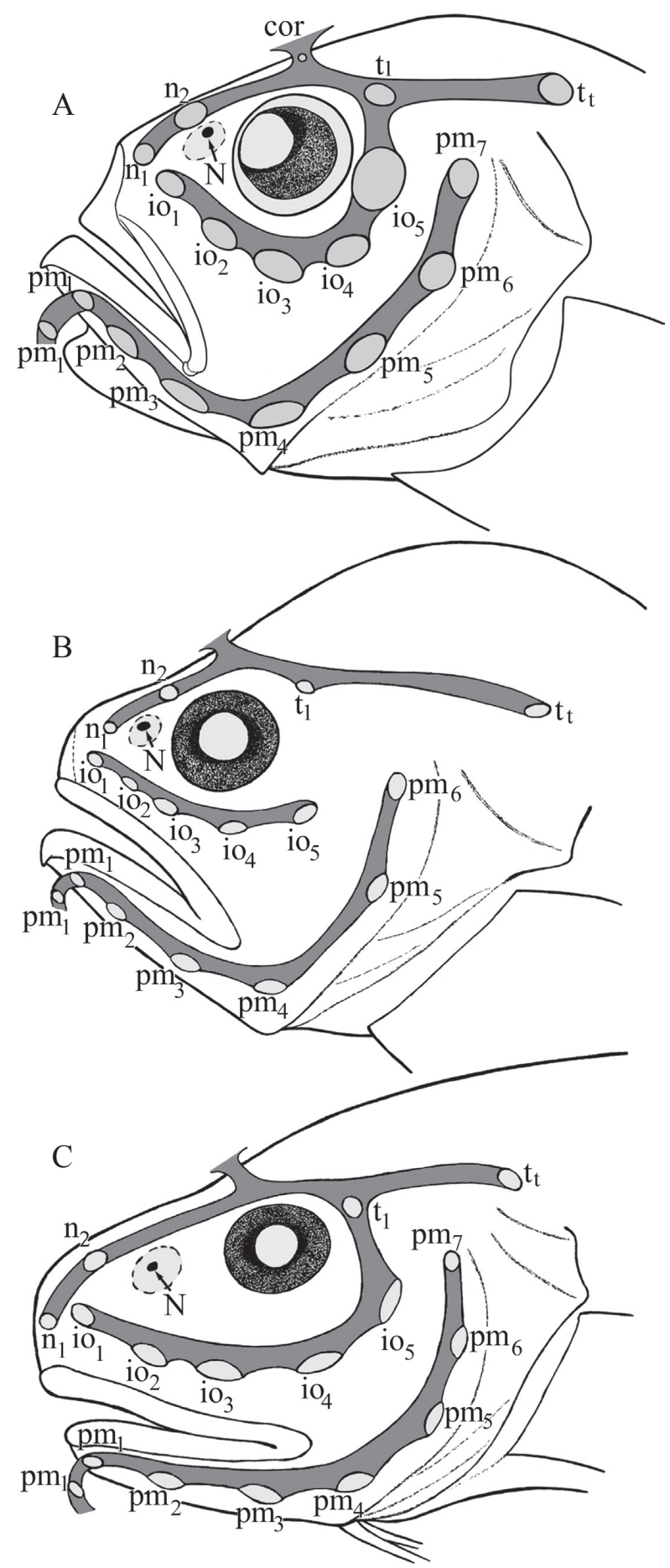

Figure 9. Configuration of the cephalic lateral line system (schematized) in three genera of Liparidae: A - Menziesichthys alaid, B - Psednos sp., C - Rhodichthys melanocephalus. Not in scale. 
the enlarged coronal and temporal pores, but this condition is opposed to that observed in Menziesichthys (infraorbital and preoperculo-mandibular pores are largest, coronal pore is smallest). The second nasal pore is positioned medial to the nostril in Menziesichthys, which represents an intermediate condition between Psednos (behind nostril) and all other liparid genera (in front of nostril). Furthermore, Menziesichthys differs from all Psednos in the possession of four very large radials equidistant from each other, lacking notches and occupying most of the surface of the basal plate (Fig. 5A) instead of three smaller radials equidistant from each other, lacking notches but having distinct spaces between them (subgenus Psednos s. str) or three radials $(2+0+1)$ with notches and interradial foramina (subgenus Protopsednos Andriashev, 2003) in Psednos.

Certain species of Paraliparis share some characters of Menziesichthys, i.e., enlarged gill slit (though in Paraliparis the slit never reaches the lower end of the pectoral-fin base), oblique mouth, very large sensory pore openings, low number of pectoral-fin rays, diminutive size, and similar structure of pectoral girdle). However, no species of Paraliparis possesses all these feature in combination. Paraliparis mandibularis Kido, 1985 from off Tosa Bay, southern Japan, is a member of that genus which is most superficially similar to Menziesichthys spp. However, it differs sharply in the pectoral-fin base extended strongly anteriad with pectoral symphysis positioned well in front of the anterior border of the orbit; gill opening, though rather large ( $45.9 \% \mathrm{SL}$ ), situated wholly above pectoral-fin base; number of pectoral-fin rays higher (27-30) (no data about pectoral girdle structure); sensory pore openings small; body not humpbacked (no anterior flexion of vertebral column); and larger size (attaining at least $122 \mathrm{~mm} \mathrm{SL}$ ).

The genus Rhodichthys was synonymized with Paraliparis by Kido (1988) and Orr et al. (2019) (Psednos was not included in their analysis); however, for current purposes we accept the classification proposed by Knudsen et al. (2007) and treat Rhodichthys as a separate genus. Menziesichthys and Rhodichthys are unique within the family in possessing a large gill slit extending more or less before the lower end of pectoral-fin base (far before in Menziesichthys, but only slightly before in Rhodichthys, vs. not reaching the lower end of the pectoral-fin base in all other liparid genera; in Psednos usually mostly or fully above the upper end of the pectoral-fin base).

On the basis of these characters we, therefore, retain Menziesichthys as a distinct genus diagnosable from Psednos, Rhodichthys and Paraliparis by the unique combination of features as summarized in Table 2.

As Menziesichthys has many morphological similarities with Rhodichthys and Psednos, it is also possible to speculate that all three genera may be eventually combined as one. However, such a conglomerate of species will be completely inseparable from the highly diverse (both morphologically and taxonomically) and complex genus Paraliparis. We believe this would be impractical, as Menziesichthys, Rhodichthys and Psednos each represent morphologically easily diagnosable units. Separation of these genera appears to be the most justified action with the current 
Table 2. Diagnostic characters separating Menziesichthys from morphologically similar liparid genera.

\begin{tabular}{|c|c|c|c|c|}
\hline Character & Menziesichthys & Psednos & Rhodichthys & Paraliparis \\
\hline $\begin{array}{l}\text { Anterior flexion } \\
\text { of vertebral } \\
\text { column }\end{array}$ & $\begin{array}{l}\text { Present, } \\
\text { conspicuous } \\
\text { (Fig. 5D) }\end{array}$ & $\begin{array}{l}\text { Usually present, } \\
\text { variably } \\
\text { expressed; absent } \\
\text { in one species }\end{array}$ & Absent & Absent \\
\hline Second nasal pore & $\begin{array}{l}\text { Medially to } \\
\text { nostril } \\
\text { (Figs 2D, 9A) }\end{array}$ & $\begin{array}{l}\text { Behind nostril } \\
\text { (Fig. 9B) }\end{array}$ & $\begin{array}{l}\text { In front of nostril } \\
\text { (Fig. 9C) }\end{array}$ & In front of nostril \\
\hline Infraorbital canal & $\begin{array}{l}\text { Uninterrupted } \\
\text { (Fig. 9A) }\end{array}$ & $\begin{array}{l}\text { Interrupted } \\
\text { (Fig. 9B) }\end{array}$ & $\begin{array}{l}\text { Uninterrupted } \\
\text { (Fig. 9C) }\end{array}$ & Uninterrupted \\
\hline Gill slit & $\begin{array}{l}\text { Very large, } \\
\text { ending in front } \\
\text { of ventral ends of } \\
\text { pectoral-fin bases }\end{array}$ & $\begin{array}{l}\text { Moderate to } \\
\text { small, ending far } \\
\text { behind ventral } \\
\text { ends of pectoral- } \\
\text { fin bases }\end{array}$ & $\begin{array}{l}\text { Very large, } \\
\text { ending in front } \\
\text { of ventral ends of } \\
\text { pectoral-fin bases }\end{array}$ & $\begin{array}{l}\text { Variable in } \\
\text { size between } \\
\text { the species but } \\
\text { never reaching } \\
\text { ventral ends of } \\
\text { pectoral-fin bases }\end{array}$ \\
\hline $\begin{array}{l}\text { Protrusion at } \\
\text { posterior end } \\
\text { of maxilla }\end{array}$ & $\begin{array}{l}\text { Minute to well- } \\
\text { developed }\end{array}$ & Absent & Absent & Absent \\
\hline Pectoral fin & $\begin{array}{l}\text { With a shallow } \\
\text { notch; all rays } \\
\text { visible externally }\end{array}$ & $\begin{array}{l}\text { With a shallow to } \\
\text { moderately deep } \\
\text { notch; all rays } \\
\text { visible externally }\end{array}$ & $\begin{array}{l}\text { Subdivided (some } \\
\text { middle rays not } \\
\text { externally visible; } \\
2-3 \text { lowermost } \\
\text { rays forming a } \\
\text { "pseudoventral" } \\
\text { fin and widely } \\
\text { separated from } \\
\text { the upper lobe) }\end{array}$ & $\begin{array}{l}\text { Variable between } \\
\text { the species } \\
\text { from almost } \\
\text { unnotched to } \\
\text { subdivided; if } \\
\text { some middle rays } \\
\text { not externally } \\
\text { visible, the } \\
\text { upper and lower } \\
\text { lobe not widely } \\
\text { separated }\end{array}$ \\
\hline Pectoral radials & $\begin{array}{l}4 \text {, occupies most } \\
\text { surface of the } \\
\text { basal plate }\end{array}$ & $\begin{array}{l}3 \text { (as exception, } \\
4 \text { ), small; basal } \\
\text { plate largely } \\
\text { exposed }\end{array}$ & $\begin{array}{l}3 \text { (rarely } 4 \text { ), } \\
\text { small; basal plate } \\
\text { largely exposed }\end{array}$ & $\begin{array}{l}\text { Variable between } \\
\text { the species }\end{array}$ \\
\hline
\end{tabular}

state of knowledge, although further anatomical and molecular studies (not possible at present) may give reasons for a different viewpoint.

All known specimens of Menziesichthys spp. were collected by bottom trawls with non-closing openings. This does not exclude the possibility of catching of these specimens during a reeling-in of gear. However, the intestine and pyloric caeca of the paratype of $M$. alaid are fully filled by fine-grained detritus, suggesting bottom feeding. Thus, Menziesichthys may have a bottom-dwelling (like Rhodichthys) rather than mesopelagic (like Psednos) mode of life. 


\section{Conclusion}

Validity of the genus Menziesichthys and its reinstatement to the family Liparidae are confirmed. Menziesichthys is re-diagnosed based on the re-examination of the holotype of M. bacescui from the Peru-Chile Trench, and the examination of two additional specimens from the Sea of Okhotsk belonging to the new species $M$. alaid. Menziesichthys appears to be morphologically intermediate between the genera Psednos and Rhodichthys (Table 2). It is similar to Psednos in possessing a humpbacked body formed by an anterior flexion of the vertebral column, oblique mouth and small adult size, and to Rhodichthys in possessing a large gill slit, large openings of the cephalic sensory pores, and uninterrupted infraorbital canal. It differs from these genera in the second nasal pore medial to the nostril, fleshy protrusion at the posterior end of the maxilla, and four large pectoral bony radials occupying most of the basal plate. Species of Menziesichthys differ from each other principally by the number of the pectoral-fin rays, position of the anus, size of the fleshy protrusion at the posterior end of the maxilla, and of the olfactory organ (see key below).

- Pectoral fin with 24 rays; anus situated about twice closer to anal-fin origin than to chin; fleshy protrusion at end of maxilla long, barbel-like; longest diameter of olfactory organ $5.0 \%$ HL; Peru-Chile Trench .......... M. bacescui

- Pectoral fin with 13-14 rays; anus equidistant from anal-fin origin and from chin or slightly closer to chin; fleshy protrusion at end of maxilla minute, knob-like; longest diameter of olfactory organ 9.5-10.0 \% HL; Sea of Okhotsk M. alaid

\section{Comparative material examined}

Liparis frenatus (Gilbert \& Burke, 1912). IOM nr. 3608, 2 specimens 43 and $70 \mathrm{~mm}$ SL, 495 $50^{\prime} \mathrm{N}, 155^{\circ} 55^{\prime} \mathrm{E}, 106 \mathrm{~m}$, R/V Vityaz, sta. 2766, Sigsbee trawl, 22.05.1954. Paraliparis albeolus Schmidt, 1950. IOM nr. 3600, 4 specimens, 50-53 mm SL, 50 $30^{\prime} \mathrm{N}, 155^{\circ} 18^{\prime}$ E, 806-795 m, R/V Akademik Mstislav Keldysh, cruise 11A, sta. 1397, sample 2, Sigsbee trawl, 30.06.1986. IOM nr. 3601, 2 specimens, 68 and 84 $\mathrm{mm} \mathrm{SL}, 49^{\circ} 30^{\prime} \mathrm{N}, 155^{\circ} 20^{\prime} \mathrm{E}, 120-0 \mathrm{~m}, \mathrm{R} / \mathrm{V}$ Vityaz, sta. 155, large beam-trawl, 07.10.1949.

Paraliparis australis Gilchrist, 1902. IOM nr. 3606, 1 specimen, $52 \mathrm{~mm}$ SL, off Namibia, $\sim 25^{\circ} \mathrm{S}, \sim 10^{\circ}$ E, 200-0 m, R/V Akademik Kurchatov, cruise 43, sta. 4926, sample 26, modified Isaacs-Kidd trawl, 18.01.1986.

Paraliparis barbulifer (Gilbert, 1896). IOM nr. 3602, 12 specimens, 45-95 mm SL, $50^{\circ} 28^{\prime} \mathrm{N}, 155^{\circ} 21^{\prime}$ E, 644 m, R/V Akademik Mstislav Keldysh, cruise 11A, sta. 1401, sample 4, Sigsbee trawl, 01.07.1986.

Paraliparis cf. hubbsi Andriashev, 1986. IOM nr. 3611, 1 specimen, 117 mm SL, South-Western Atlantic, 44-53 S, 57-59 W, FRV Zvezda Kryma, 1974. 
Paraliparis mandibularis Kido, 1985. BSKU nr. 30513, holotype, $107 \mathrm{~mm} \mathrm{SL}$, 32 $57.3^{\prime} \mathrm{N}, 133^{\circ} 32^{\prime} \mathrm{E}, 605 \mathrm{~m}, 21.12 .1979$.

Psednos spp. IOM nr. 3603, 1 specimen, $73 \mathrm{~mm} \mathrm{SL}, 43^{\circ} 42^{\prime} \mathrm{N}, 52^{\circ} 26^{\prime} \mathrm{W}, 720 \mathrm{~m}$, FRV Perseus-III, cruise 37, trawl 118, 04.04.1987. IOM nr. 3607, 1 specimen,

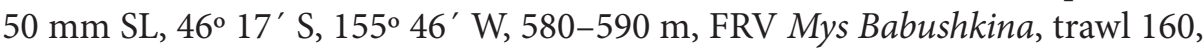
01.06 .1980 .

NB. Both specimens are not identifiable to the species level using the keys of Chernova (2001), Chernova and Stein (2002), Andriashev (2003) and Stein (2012b).

Rhodichthys melanocephalus Andriashev et Chernova, 2010. IOM nr. 3604, 5 specimens, 73-111 mm SL, $77^{\circ} 24.5^{\prime} \mathrm{N}, 125^{\circ} 47.7^{\prime} \mathrm{E}, 1500 \mathrm{~m}$, R/V Akademik Mstislav Keldysh, cruise 72, sta. 5954, Sigsbee trawl, 29.08.2018. IOM nr. 3605, 2 specimens, 110 and $178 \mathrm{~mm} \mathrm{SL}, 73^{\circ} 43^{\prime}-73^{\circ} 40^{\prime} \mathrm{N}, 13^{\circ} 23^{\prime}-13^{\circ} 17^{\prime} \mathrm{E}, 1665-1610$ m, R/V Akademik Mstislav Keldysh, cruise 31, sta. 3177, 18.08.1993.

NB. We agree with Mecklenburg et al. (2018) that separation of $R$. melanocephalus from $R$. regina Collett, 1879 is questionable, as our specimens are also morphologically intermediate, but for current purposes we follow Andriashev and Chernova (2010) in taxonomic treatment of Rhodichthys pending further more comprehensive revision.

\section{Acknowledgements}

We are grateful to Hiromitsu Endo (Kochi University) for preparing of the photoand radiographs of the holotype of Paraliparis mandibularis, to Alexey V. Mishin (P. P. Shirshov Institute of Oceanology, Moscow) for donation of the specimens of Rhodichthys collected in the 72th cruise of R/V Akademik Mstislav Keldysh, to Aurora Dinu ("Grigore Antipa" National Museum of Natural History) for the ink-drawing picture of Menziesichthys bacescui, to Melanya Stan, Iorgu Petrescu, Andreea Drăghici and other personnel of "Grigore Antipa" National Museum of Natural History for assistance in working with the holotype of Menziesichthys bacescui. We are sincerely indebted to the reviewers of our paper for their helpful suggestions and improvements. The work of the first author was supported by a grant (19-14-00026) of the Russian Science Foundation.

\section{References}

Andriashev AP (1986) Review of the snailfish genus Paraliparis (Scorpaeniformes: Liparididae) of the Southern Ocean. Theses Zoologicae 7: i-iv + 1-204.

Andriashev AP (1992) Morphological evidence for the validity of the antitropical genus Psednos Barnard (Scorpaeniformes, Liparididae) with a description of a new species from the eastern North Atlantic. Uo (Japanese Society of Ichthyology) (41): 1-18. 
Andriashev AP (2003) Liparid fishes (Liparidae, Scorpaeniformes) of the Southern Ocean and adjacent waters. Serie "Results of the Russian Antarctic Expeditions", 9. Exploration of the faunas of the seas 53(61): 1-476. [in Russian, with English summary].

Andriashe AP, Chernova NV (2010) Three new snailfishes (Scorpaeniformes: Liparidae) from bathyal depths of the Arctic. Proceedings of the Zoological Institute of RAS 314 (4): 365-380. [in Russian, with English diagnoses and summary].

Andriashev AP, Neelov AV, Prirodina VP (1977) On methods of study of the morphology and systematics of the fish family of sea snails (Liparidae). Zoologicheskij Zhurnal 56 (1): 141-147 [in Russian].

Andriashev AP, Stein DL (1998) Review of the snailfish genus Careproctus (Liparidae, Scorpaeniformes) in Antarctic and adjacent waters. Contribution in Science, Natural History Museum of Los Angeles County (470): 1-63.

Balushkin AV (1996) A new genus and species of liparid fish Palmoliparis beckeri from the northern Kuril Islands (Scorpaeniformes, Liparidae) with consideration of phylogeny of the family. Voprosy Ikhtiologii 36(3): 293-299. [in Russian].

Burke CV (1930) Revision of the fishes of the family Liparidae. Bulletin of the United States National Museum 150: i-xii + 1-204.

Chernova NV (2001) A review of the genus Psednos (Pisces, Liparidae) with description of ten new species from the North Atlantic and southwestern Indian Ocean. Bulletin of the Museum of Comparative Zoology 155(10): 477-507.

Chernova NV, Stein DL (2002) Ten new species of Psednos (Pisces, Scorpaeniformes: Liparidae) from the Pacific and North Atlantic Oceans. Copeia (3): 755-778.

Chernova NV, Stein DL (2004) A remarkable new species of Psednos (Teleostei: Liparidae) from the western North Atlantic Ocean. Fishery Bulletin 102(2): 245-250.

Chernova NV, Stein DL, Andriashev AP (2004) Family Liparidae Scopoli 1777—snailfishes. California Academy of Sciences Annotated Checklists of Fishes (31): 1-72.

Duhamel G, Hautecoeur M, Dettai A, Causse R, Pruvost P, Busson F, Couloux A, Koubbi P, Williams R, Ozouf-Costaz C, Nowara G (2010) Liparids from the eastern sector of Southern Ocean and first information from molecular studies. Cybium 34(4): 319-343.

Fricke R, Eschmeyer WN (2020) Guide to fish collections. (http://researcharchive. calacademy.org/research/ichthyology/catalog/collections.asp). Electronic version accessed 05.01.2020.

Fricke R, Eschmeyer WN, van der Laan R (2020) Catalog of Fishes: Genera, Species, References. (http://researcharchive.calacademy.org/research/ichthyology/catalog/ fishcatmain.asp). Electronic version accessed 05.01.2020.

Kido K (1988) Phylogeny of the family Liparididae, with the taxonomy of the species found around Japan. Memoirs of the Faculty of Fisheries, Hokkaido University 35(2): 125-256. Knudsen SW, Møller PR, Gravlund P (2007) Phylogeny of the snailfishes (Teleostei: Liparidae) based on molecular and morphological data. Molecular Phylogenetics and Evolution 44(2): 649-666.

Mecklenburg CW, Lynghammar A, Johannesen E, Byrkjedal I, Christiansen JS, Dolgov AV, Karamushko OV, Mecklenburg TA, Møller PR, Steinke D, Wienerroither RM (2018) 
Marine fishes of the Arctic region. Volume 1. Conservation of Arctic flora and fauna, Akureyri, Iceland, $454 \mathrm{pp}$.

Nakabo T (2002) Liparidae snailfishes. In: Nakabo T (Ed.) Fishes of Japan with pictorial keys to the species. Volume 1. Tokai Univ. Press, Tokyo, 665-677.

Nalbant TT, Mayer RF (1971) New and rare species of fishes from the Peru-Chile Trench, collected during the 11th cruise of the R/V “Anton Bruun" (1965). Revue Roumaine de Biologie. Serie Zoologie 16(5): 315-324.

Orr JW, Spies I, Stevenson DE, Longo GC, Kai Y, Ghods S, Hollowed M (2019) Molecular phylogenetics of snailfishes (Cottoidei: Liparidae) based on MtDNA and RADseq genomic analyses, with comments on selected morphological characters. Zootaxa 4642: $1-79$.

Stein DL (1978) The genus Psednos a junior synonym of Paraliparis, with a redescription of Paraliparis micrurus (Barnard) (Scorpaeniformes: Liparidae). Matsya (4): 5-10.

Stein DL (2012a) Snailfishes (Family Liparidae) of the Ross Sea, Antarctica, and closely adjacent waters. Zootaxa 3285: 1-120.

Stein DL (2012b) A review of the snailfishes (Liparidae, Scorpaeniformes) of New Zealand, including descriptions of a new genus and sixteen new species. Zootaxa 3588: 1-54.

Stein DL, Chernova NV, Andriashev AP (2001) Snailfishes (Pisces: Liparidae) of Australia, including descriptions of thirty new species. Records of the Australian Museum 53: 341-406.

Stein DL, Meléndez RC, Kong IU (1991) A review of Chilean snailfishes (Liparididae, Scorpaeniformes) with descriptions of a new genus and three new species. Copeia (2): 358 373. 